The Plant Diseases of Great Britain :

a Bibliography. Compiled and annotated by Dr. G. C. Ainsworth. Pp. xii +273 . (London: Chapman and Hall, Ltd., 1937.) 15s. net.

This book, to which Dr. E. J. Butler has contributed a foreword, is a successful attempt to provide the plant pathologist-at rather a high price-with the key references to the literature on the principal plant diseases of Great Britain. The 183 host plants are conveniently arranged in groups as in the Ministry of Agriculture's reports on the annual occurrence of plant diseases, from which most of the nine hundred diseases included were taken. Under each host there is a list of diseases that may affect the plant and, where possible, the common names applied to these diseases are those recommended by the Plant Pathology Committee of the British Mycological Society. The attempt to name viruses and virus diseases will be particularly welcomed by plant pathologists. A selected list of literature references, mainly English but with a sprinkling of foreign papers, is given for the majority of the diseases, and each reference is briefly annotated to indicate.the contents of the paper. Where a paper is abstracted in the Review of Applied Mycology a reference to this is given. Two indexes are provided, one of authors and one of hosts and parasites.

The selection of the English literature has been extremely well made, but many quite uncommon or doubtfully parasitic diseases are included without comment. Indeed, the value of the book to economic workers, both in Great Britain and Overseas, would have been greatly increased if the author had attempted to assess the relative importance of the diseases, for the number of articles published about a particular disease is apt to give a very misleading impression of its economic significance. The references have evidently been carefully checked, but elsewhere misprints are frequent.

W. C. M.

\section{Commercial A.C. Measurements}

By G. W. Stubbings. Second edition, revised. Pp. xvi + 348. (London : Chapman and Hall, Ltd., 1937.) $15 s$. net.

THIs book has been written primarily for testing engineers. For students reading for engineering examinations it will not be so useful, as there are no examples given to illustrate the application of the theory given to practical work. The author has reduced the mathematical theory to a minimum, and so does not discuss the cases where three vectors cannot be represented by three lines lying in one plane, or stated the full conditions that must be satisfied in order that the power factor of a circuit may be unity.

The author's descriptions are easy to follow and he is thoroughly familiar with the methods used in the testing departments of power stations. Apparently it is customary to express the errors of watt-hour meters as a percentage of the true registration, the number being + (positive) if the meter is fast and - (negative) if it is slow. The average consumer would probably understand the meter card more easily if fast were written for + and slow for - It is quite unnecessary to burden the memory in this case.
Handbook of Engineering Fundamentals

Prepared by a Staff of Specialists under the Editorship of Ovid W. Eshbach. (Wiley Engineering Handbook Series, Vol. I.) Pp. xii $+1036+50$. (New York : John Wiley and Sons, Inc.; London: Chapman and Hall, Ltd., 1936.) 25s. net.

THIS book is divided into thirteen sections beginning with mathematical and physical tables and proceed. ing through such other subjects as mathematics, mechanics, flow of fluids, thermodynamics, electricity and magnetism, radiation, light, acousties and meteorology, chemistry, metallic and non-metallic materials, to a final section on contracts, and certainly deals with the fundamental subjects required by the engineer.

The forty authors responsible for this work have been selected in equal numbers from the academic and industrial fields, so that, whilst the theoretical aspects of the various subjects are not overlooked, the practical applications of the theories receive due attention.

Intended as an introduction to the two volumes comprising Kent's "Engineering Handbook", and the two volumes constituting the "Handbook for Electrical Engineers", all of which are of uniform size, it possesses much useful information, but the English reader must always remember that it treats of American practice. Although containing nearly eleven hundred pages, the book is of convenient size, clearly printed, well illustrated, and firmly bound in flexible covers; it should prove a useful addition to the library of the engineer.

\section{The Metabolism of Living Tissues}

By Dr. Eric Holmes. Pp. xi +235 . (Cambridge : At the University Press, 1937.) 7s. 6d. net.

SrR F. Gowland HopkINs has written a foreword in which he calls this a highly original book. Its chief claim to originality probably lies in its popular style, which strays from the narrow vocabulary generally used in scientific works in a way that is likely to shock the purists. The book is meant to be read straight through by students of biochemistry at the beginning of their course, and is likely to appeal to such readers. Advantage has been taken of the fact that the contemplation of structural formulæ brings æsthetic satisfaction to many who do not really understand them. Such contemplation is encouraged by an invitation to compare the formula of the lactoflavin in vitamin $B_{2}$ with the prosthetic group of Warburg's yellow pigment. The two substances are identical, but it takes the beginner some time to discover this fact because the two versions of the formula are written differently.

After some general remarks about enzymes, oxidations and redox potentials, the metabolism of the liver, kidney, muscles and nervous system are discussed in separate chapters, with particular emphasis on carbohydrate metabolism. This is probably the best part of the book. Hormones and vitamins are mentioned in later chapters, and their formulæ given. The book is intended as an introduction. There is a danger that it will come to be regarded by students as a complete account of all that they need to know. 